\title{
Mapping of Seawater Intrusion into Coastal Aquifer: A Case Study of Pekalongan Coastal Area in Central Java
}

\author{
Muh. Irham Sahana*, Roh Santoso Budi Waspodo \\ Department of Civil and Environmental Engineering, IPB University, Bogor, INDONESIA \\ Kampus IPB Darmaga, Bogor, Jawa Barat \\ ${ }^{*}$ Corresponding authors: irham_sahana@apps.ipb.ac.id
}

SUBMITTED 24 January 2020 REVISED 06 March 2020 ACCEPTED 06 March 2020

\begin{abstract}
Seawater intrusion promotes the degradation of groundwater quality through excessive pumping activities or natural phenomena such as tidal floods which are popular with coastal areas. Pekalongan city is one of the areas affected by this phe nomenon and was analyzed in this study with reference to the 1986 Ad Hoc Sea Water Intrusion (PAHIAA) Decree which classifies water into five based on salinity. This involved using the Integrated Distance Method (IDW) to map and applying the logarithmic equation to determine the dispersion relationship. The results showed seawater intrusion has already affected groundwater quality up to $6.52 \mathrm{~km}$ from the coastline for total dissolved solids and electrical conductivity and $7.22 \mathrm{~km}$ for chloride ion. The distribution of TDS, EC, and $\mathrm{Cl}^{-}$in the freshwater zone was also recorded to have reached $28.59 \mathrm{~km}^{2}, 28.36 \mathrm{~km}^{2}$, and $23.95 \mathrm{~km}^{2}$ respectively. It is predicted that in 4 years, there would no longer be freshwater in Padukuhan Kraton Village due to decreasing groundwater quality caused by seawater intrusion. Furthermore, $23.03 \mathrm{~km}^{2}$ Pekalongan area which spread into $4.34 \mathrm{~km}^{2}$ to the West, $0 \mathrm{~km}^{2}$ to the South, $14.39 \mathrm{~km}^{2}$ to the North, and $1.28 \mathrm{~km}^{2}$ to the East of the district has also been affected and was discovered to be caused mainly by tidal flood from Bremi and Tirto rivers.
\end{abstract}

KEYWORDS Groundwater; Coastal Area; Salinity; Seawater Intrusion; Tidal Flood

(c) The Author(s) 2020. This article is distributed under a Creative Commons Attribution-ShareAlike 4.0 International license.

\section{INTRODUCTION}

Seawater has the ability to influence groundwater quality and quantity through the intrusion and sea-level rise phenomenon. According to Melo, M.T.C, (2015) seawater intrusion is the migration of seawater into freshwater aquifers under the influence of groundwater development. It is triggered by several factors such as excessive pumping, land-use change, reduction in recharge because of global warming, and overtopping caused by sea-level rise, storm surges, and tsunamis. Meanwhile, the increase in water withdrawals from wells has also caused unacceptable drawdowns and deterioration in quality. Fresh groundwater in the coastal aquifer is drained into seas or lakes under natural conditions and this creates an interface line between fresh and salt-water. The massive exploitation of coastal aquifers also been reported to have an impact on the evolution of hydraulic gradient. This phenomenon is called seawater intrusion (Naderi, M.N., et al., 2013).

Seawater intrusion has a significant effect on human living such as health disruption, decreasing soil fertility, and causing damage to buildings, especially for people living in coastal areas (Widada, S, 2007). One of the areas substantially associated with this problem is Pekalongan City which is located on the northern coast of Central Java Province, Indonesia. A preliminary investigation attributed the seawater intrusion experienced in the area, especially the North and West Districts, to the tidal flood inundating the area since 2013 as well as daily freshwater withdrawal from shallow wells. The increasing exploitation of groundwater over time 
is thought to induce seawater intrusion in the coastal aquifer. This means it involves replacing groundwater in aquifers by seawater thereby making the freshwater in some wells brackish. Therefore, the objective of this study was to investigate seawater intrusion based on the relationship of electrical conductivity (EC), total dissolved solids (TDS), and chloride ion (CL) to the distance of the well from the coast.

\section{METHODS}

This research was conducted in Pekalongan City which has 4 Districts and the highest number of sampling points were found in the North and West due to the occurrence of tidal floods. Both primary and secondary data were used. The secondary data composed of the administrative map, Digital Elevation Map (DEM) data, and shapefile data of Pekalongan City collected and used to decide the sampling point locations.

The primary data included the unconfined groundwater samples collected from 64 shallow wells in the 4 districts. Moreover, groundwater concentration was measured in the North and West districts with 20 and 22 points, respectively. The distribution of the sampling point is shown in Figure 1. Furthermore, the AMTAST AMT03R instrument was used to measure the electrical conductivity (EC), total dissolved solids (TDS), and chloride ion $\left(\mathrm{Cl}^{-}\right)$contents in the water after which the results were analyzed by considering the coordinates of the location and distance from the coast. A regression curve was also employed to improve the accuracy of the results.

The dispersion map of seawater intrusion was based on the groundwater quality parameters with reference to the 1986 Ad Hoc Sea Water Intrusion (PAHIAA) Committee Decree presented in Widada, S, (2007). The qualities were classified into five including fresh, rather brackish, brackish, salty, and brine with the details shown in Table 1. Moreover, the data were analyzed based on the values of electrical conductivity (EC), total dissolved solids (TDS), and chloride $\left(\mathrm{Cl}^{-}\right)$.

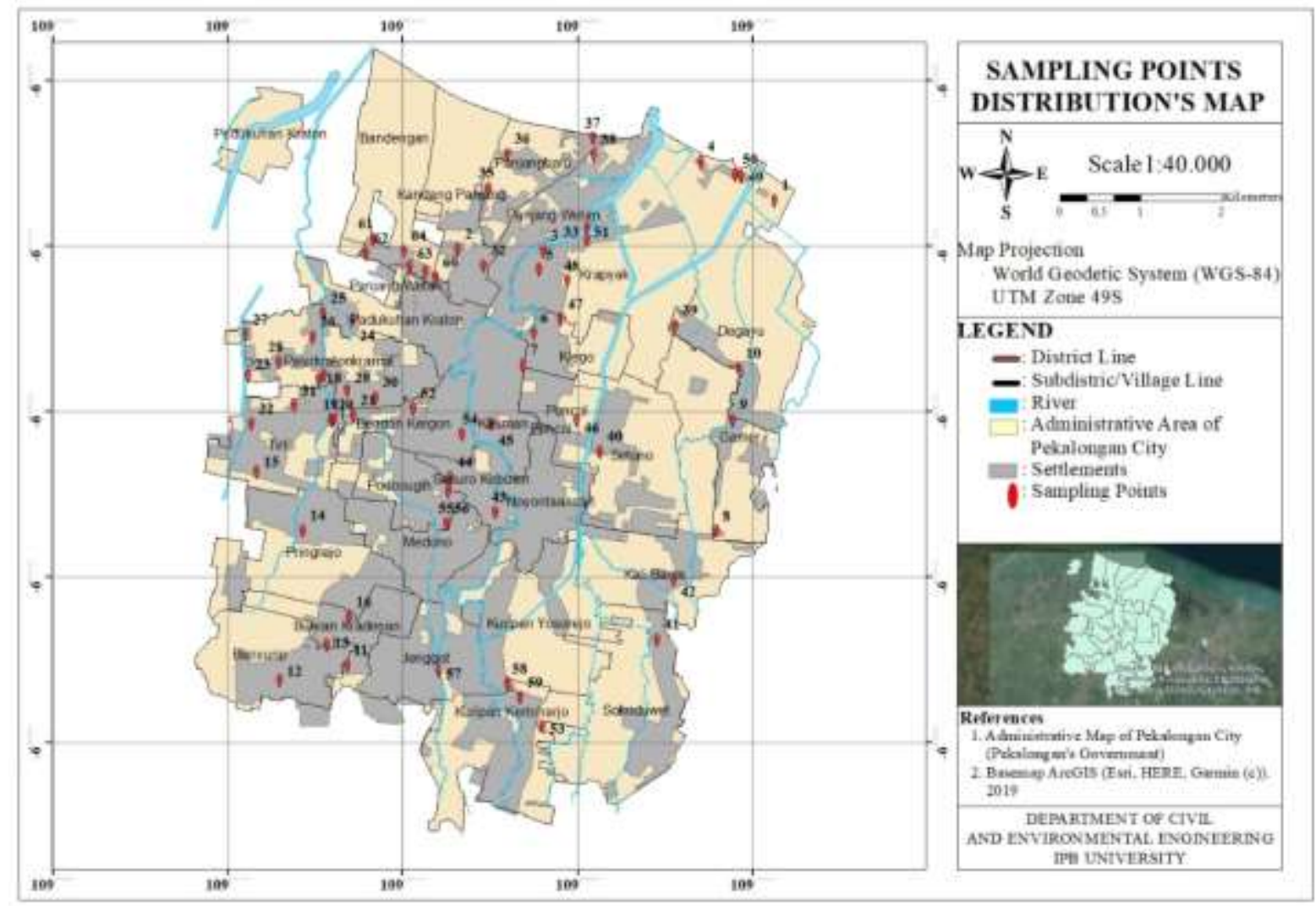

Figure 1. Distribution of sampling points 
Table 1. Classification of groundwater salinity level referred to PAHIAA, 1986

\begin{tabular}{llll}
\hline Water Quality & TDS $(\mathrm{mg} / \mathrm{L})$ & EC $(\mu \mathrm{mhos} / \mathrm{cm})$ & $\mathrm{Cl}^{-}(\mathrm{mg} / \mathrm{L})$ \\
\hline Freshwater & $<1,000$ & $<1,500$ & $<500$ \\
Rather brackish & $1,000-3,000$ & $1,500-5,000$ & $500-2,000$ \\
Brackish & $3,000-10,000$ & $5,000-15,000$ & $2,000-5,000$ \\
Salty & $10,000-35,000$ & $15,000-50,000$ & $5,000-19,000$ \\
Brine & $>35,000$ & $>50,000$ & $>19,000$ \\
\hline
\end{tabular}

This was followed by the alignment of the results from the coordinate data plotting with the parameters of EC, TDS, and $\mathrm{Cl}$ using Surfer 13 software. Furthermore, a general description of the spreading zone for the seawater intrusion was created in ArcGIS 10.4.1 software using the integrated distance weighted (IDW) method.

According to Hadi, B.S. (2018), IDW is a conventional interpolation method which considers distances as weights. The interpolation refers to the flat distance from the data or sample point to the block after which the closer distance is estimated and a higher weight created. The general weighting function is the inverse of the square distance applied in the IDW method. The advantage lies in the controllable interpolation characteristics by limiting the input points used in the process. According to Pasaribu, J.M. \& Haryani, N.S. (2012), the selection of this method compared to others such as spline and natural neighbor is based on its ability to interpolate values with considerable height differences.

\section{RESULTS AND DISCUSSION}

\subsection{Groundwater Quality Parameters}

The groundwater quality measured showed the highest concentrations of TDS, EC, and $\mathrm{Cl}^{-}$were $14,330 \mathrm{mg} / \mathrm{L}, 21,724 \mu \mathrm{mhos} / \mathrm{cm}$, and 11,360 mg/L, respectively. These values were recorded in Panjang Baru Village, North Pekalongan District located $440.22 \mathrm{~m}$ from the coast. Based on the 1986 PAHIAA classification, the groundwater was categorized as brackish due to the values of the TDS and EC parameters. Meanwhile, it was classified as salty water since the $\mathrm{Cl}^{-}$ concentration was between 5,000 to $19,000 \mathrm{mg} / \mathrm{L}$. The differences in the classifications were associated with the presence of salt ions $\left(\mathrm{Cl}^{-}\right)$ affecting the quality higher than TDS and EC which are more influenced by metal elements. The concentration was also believed to be influenced by surrounding environmental conditions such as the prevalence of tidal floods or sea tides which usually leads to the easy infiltration and concentration of salt and metals.

The lowest concentration was recorded in Kuripan Yosorejo Village, South Pekalongan District located 6,954.12 $\mathrm{m}$ from the coast. TDS, $\mathrm{EC}$, and $\mathrm{Cl}^{-}$had $142 \mathrm{mg} / \mathrm{L}, 213 \mu \mathrm{mhos} / \mathrm{cm}$, and 104 $\mathrm{mg} / \mathrm{L}$ respectively. Therefore, the groundwater in the area was classified as freshwater because the TDS concentration is less than $1000 \mathrm{mg} / \mathrm{L}$, EC concentration is below $1500 \mu \mathrm{mhos} / \mathrm{cm}$, and the salinity level is less than $500 \mathrm{mg} / \mathrm{L}$. Meanwhile, from the measurements in West Pekalongan District, the TDS ranged between 332 and 12356.8 $\mathrm{mg} / \mathrm{L}$, EC was 499 to $18740.02 \mu \mathrm{mhos} / \mathrm{cm}$, and $\mathrm{Cl}^{-}$ was between 249 to $9798 \mathrm{mg} / \mathrm{L}$. The highest concentration was obtained around the Tirto River located $3.65 \mathrm{~km}$ from the coast. This affected the dispersion pattern for the seawater intrusion which tends to extend to the south direction. Moreover, in North Pekalongan District, the TDS ranged from 374 to $14,330 \mathrm{mg} / \mathrm{L}$, EC from 561 to $21,724 \mu \mathrm{mhos} / \mathrm{cm}$, and chloride was between 281 and $11,360 \mathrm{mg} / \mathrm{L}$. In addition, the maximum concentration was found at 440.2 $\mathrm{m}$ from the coast. The result indicated the intrusion pattern in North Pekalongan District was influenced by the phenomenon of tidal flood due to its geographical intersection to the coast. 
The values obtained from East Pekalongan District showed the TDS, EC, and $\mathrm{Cl}^{-}$were in the range of 314 to $844 \mathrm{mg} / \mathrm{L}, 471$ to $1,266 \mu \mathrm{mhos} / \mathrm{cm}$, and 235 to $633 \mathrm{mg} / \mathrm{L}$, respectively while at South Pekalongan District, they were 142-460 mg/L, 213 to $690 \mu \mathrm{mhos} / \mathrm{cm}$, and 104 to $345 \mathrm{mg} / \mathrm{L}$ respectively. This means the groundwater in these districts is freshwater.

\subsection{Correlation of TDS, EC, and $\mathrm{Cl}^{-}$to The Distance from The Coastline and Bremi River}

The accuracy of the total dissolved solids, electrical conductivity, and chloride ion values were evaluated based on the distance both from the shore and the Bremi River to obtain the dispersion model for all the quality parameters.

\subsubsection{Correlation of TDS, EC, and $\mathrm{Cl}^{-}$to the distance from the coastline}

The model distribution curves for TDS, $\mathrm{EC}$, and $\mathrm{Cl}^{-}$ were presented using the logarithmic regression method because it has the highest determinant coefficient or $\mathrm{R}^{2}$ approaching 1 (one) compared to other methods. The seawater intrusion was predicted by connecting the values of the parameters to the distance from the coastline. Meanwhile, the results from the dispersion model are shown in Figure 2 to Figure 4.

The curves show the values of the three parameters were decreasing as the area moves farther away from the coast. The equations used to calculate the relationship of the TDS, EC, and $\mathrm{Cl}^{-}$with the distance from the coastline were $y=-2,313 \ln (x)+20,405$ with $R^{2}$ value of 0.6615 , $y=-3,468 \ln (x)+30,597$ with $R^{2}$ value of 0.6612 , and $\mathrm{y}=-1,735 \ln (\mathrm{x})+15,307$ with 0.662 respectively. However, it was impossible to use the $\mathrm{R}^{2}$ values for regression analysis because they were less than 0.6750 or $67.50 \%$ (Drapper, N.R, \& Smith, H, 1981).

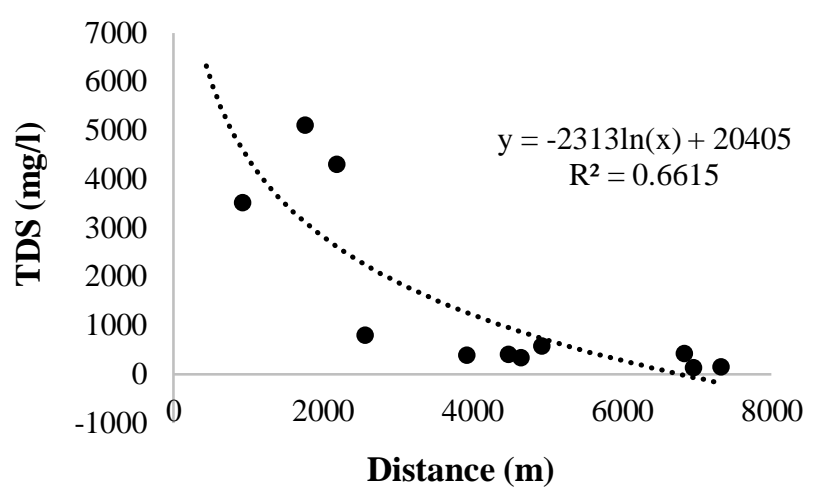

Figure 2. Model dispersion curve of TDS in shallow wells to the distance from the coastline.

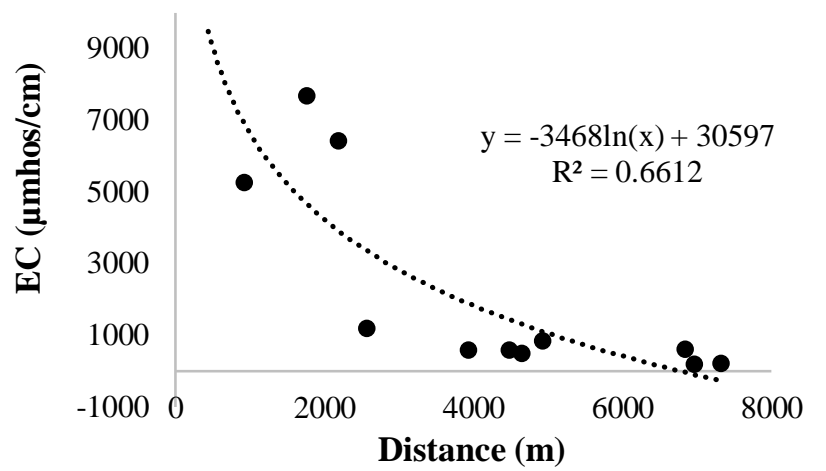

Figure 3. Model dispersion curve of EC in shallow wells to the distance from the coastline.

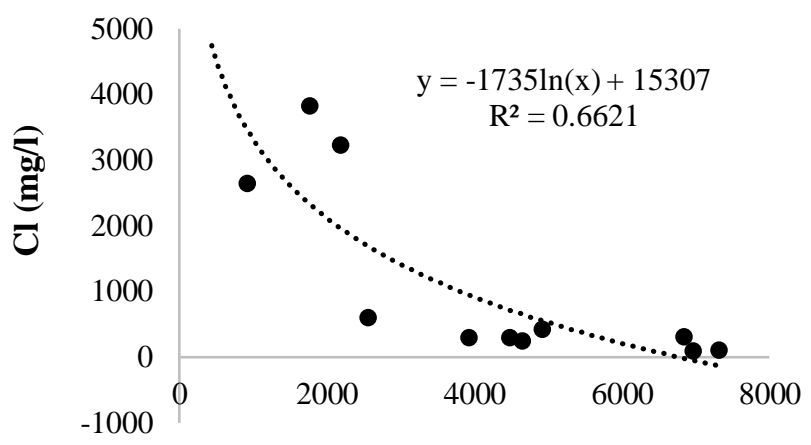

Distance (m)

Figure 4. Model dispersion curve of $\mathrm{Cl}^{-}$in shallow wells to the distance from the coastline. 


\subsubsection{Correlation of TDS, EC, and $\mathrm{Cl}^{-}$to the distance from the Bremi river}

The model distribution curves for TDS, EC, and $\mathrm{Cl}^{-}$ were presented using logarithmic regression method and even though all the parameters analyzed from the coastline have a strong relationship as indicated by the $\mathrm{R}^{2}$ values between 0.6-0.799 (Kusumarini, S, 2013), they were not suitable for regression analysis. Therefore, it was necessary to re-analyze the distance from Bremi river due to the tidal floods. Moreover, the seawater intrusion model was predicted by connecting the values of parameters to the distance from the Bremi river, and the dispersion curve and model are shown in Figure 5 to Figure 7.

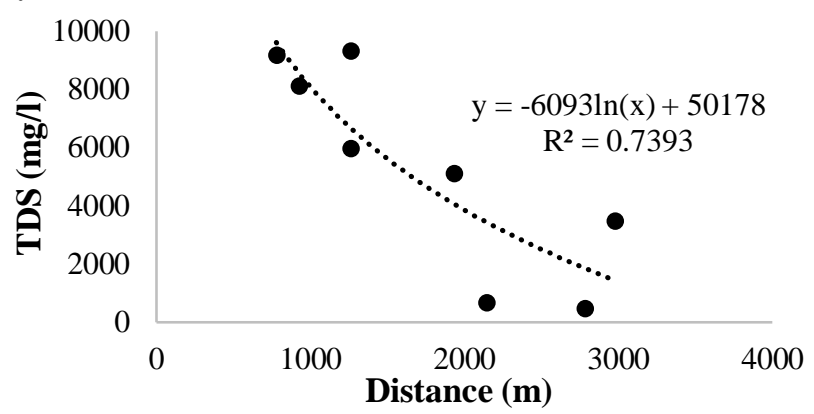

Figure 5. Model dispersion curve of TDS in shallow wells to the distance from the Bremi river.

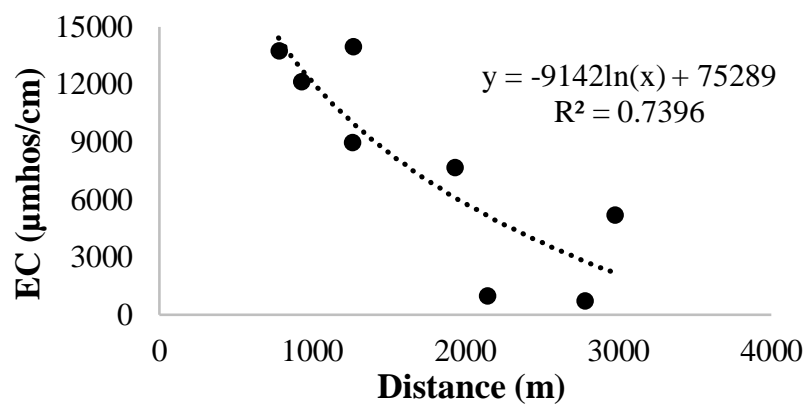

Figure 6. Model dispersion curve of EC in shallow wells to the distance from the Bremi river.

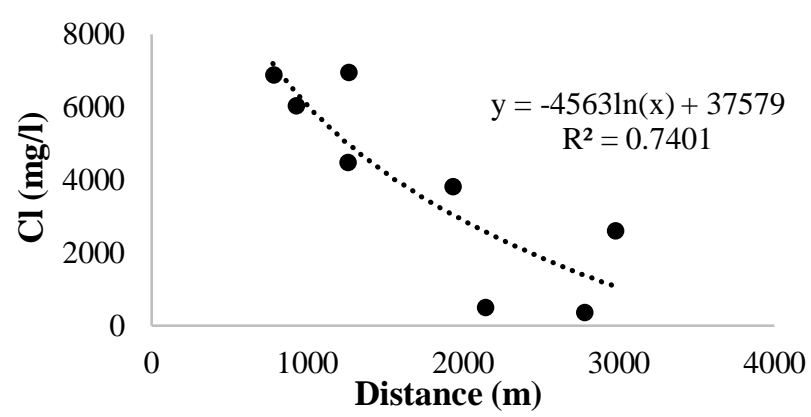

Figure 7. Model dispersion curve of $\mathrm{Cl}^{-}$in shallow wells to the distance from the Bremi river.
According to the logarithmic regression analysis, the dispersion of seawater intrusion in Pekalongan was mostly influenced by tidal flood activities from the Bremi River. This was confirmed at an accuracy level of $73.93 \%$ to $74.01 \%$ and this means it is above the $67.50 \%$ required for regression analysis (Drapper, N.R, \& Smith, H, 1981). Therefore, the relationship derived for TDS with distance was $\mathrm{y}=-6,093 \ln (\mathrm{x})+50,178$ at $\mathrm{R}^{2}$ value of 0.7393 or $73.93 \%$, EC was $\mathrm{y}=-9,142 \ln (\mathrm{x})+75,289$ at $73.96 \%$, and $\mathrm{Cl}^{-}$was $\mathrm{y}=-4,563 \ln (\mathrm{x})+37,579$ with 0.7401 or $74.01 \%$. However, linear regression analysis was also conducted but a smaller ratio of 0.7132 to 0.7139 was obtained. Therefore, the saline water was best analyzed and described using the logarithmic equation (McNeil, V, \& Cox, M.E, 2000).

\subsubsection{Correlation between TDS, EC, and $\mathrm{Cl}^{-}$}

There was a high correlation among the three parameters, therefore, the measurement data used also has high strength as shown in Figure 8 to Figure 10.

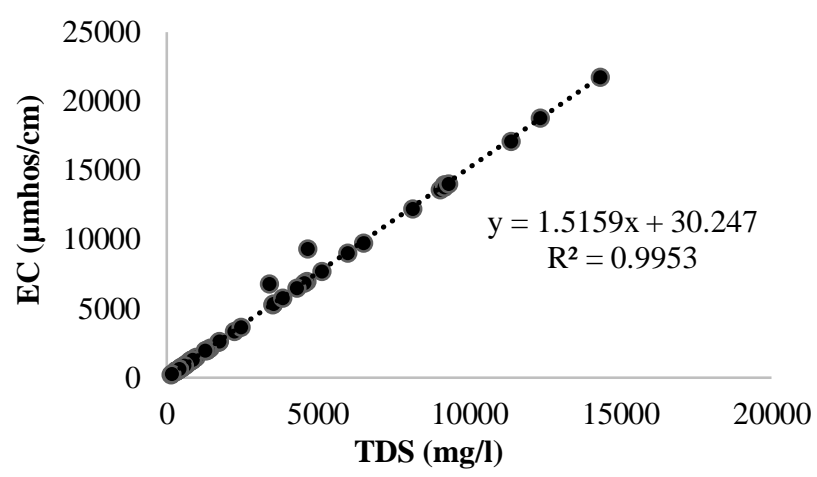

Figure 8. Correlation curve between EC and TDS.

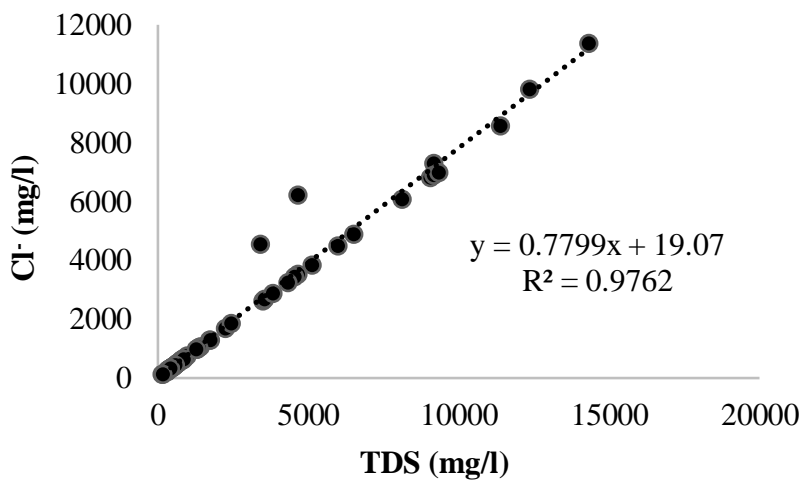

Figure 9. Correlation curve between $\mathrm{Cl}^{-}$and TDS. 


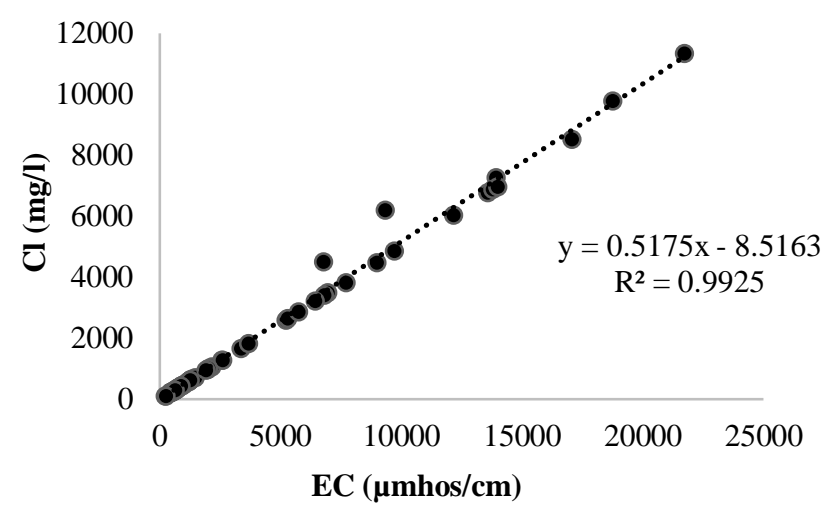

Figure 10. Correlation curve between $\mathrm{Cl}^{-}$and EC.

The correlation curve between TDS, EC, and $\mathrm{Cl}^{-}$ was found to be linear with $\mathrm{R}^{2}$ values ranged between $0.9762-0.9953$ or at an accuracy rate of 97.62\% to $99.53 \%$. This shows the three parameters had a strong relationship and the data applied too was accurate it is more than the $\mathrm{R}^{2}$ of $67.50 \%$ required for regression analysis if it is more than $67.50 \%$ (Drapper, N.R, \& Smith, H, 1981). Therefore, the linear regression equation derived for the correlation between TDS and EC was $y=1,5159 x+30,247$ at $99.53 \%$ accuracy, TDS and $\mathrm{Cl}^{-}$was $\mathrm{y}=0.7799 \mathrm{x}+19.07$ with $97.62 \%$, while $\mathrm{EC}$ and $\mathrm{Cl}^{-}$was $\mathrm{y}=0.5175 \mathrm{x}-8.5163$ with $99.25 \%$.

According to Rusydi, A.F. (2018), the variations observed mean the correlation of both parameters is strongly influenced by the EC values. Meanwhile, the high ratio between TDS and EC has almost the same correlation $\left(\mathrm{R}^{2}=0.96\right)$ (Rusydi, A.F, 2018). Moreover, all the findings are in agreement with the conclusion of McNeil, V \& Cox, M.E, (2000) that TDS/EC variation for freshwater can be within $0.5 \geqslant 1.00$ generally containing sodium, calcium, magnesium, bicarbonate type or calcium, sodium, bicarbonate, chloride type (McNeil, V, \& Cox, M.E, 2000). This, therefore, shows the most correlated major ions, especially to TDS, include chloride, sodium, and magnesium (Thirumalini, S, \& Joseph, K, 2009).

\subsection{Dispersion Analysis of Seawater Intrusion}

\subsubsection{Dispersion pattern and flow direction of seawater intrusion}

The pattern and flow direction of the seawater intrusion dispersion was analyzed with Surfer 13 software using the values of TDS, EC, and $\mathrm{Cl}^{-}$. This involved the use of contour tools such that the values were combined with grid vector map tools to determine the distribution and flow direction or flow net.

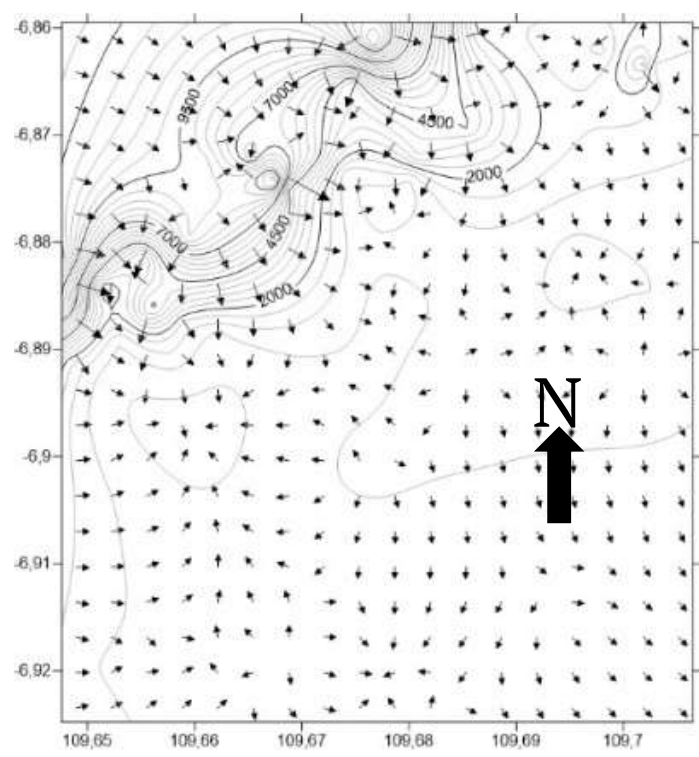

Figure 11. Pattern and flow direction of TDS.

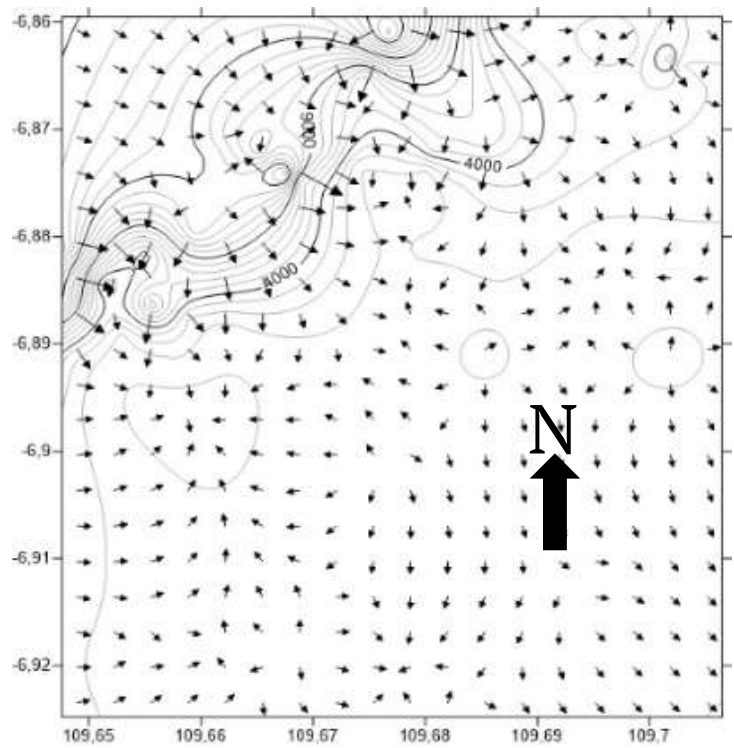

Figure 12. Pattern and flow direction of EC. 


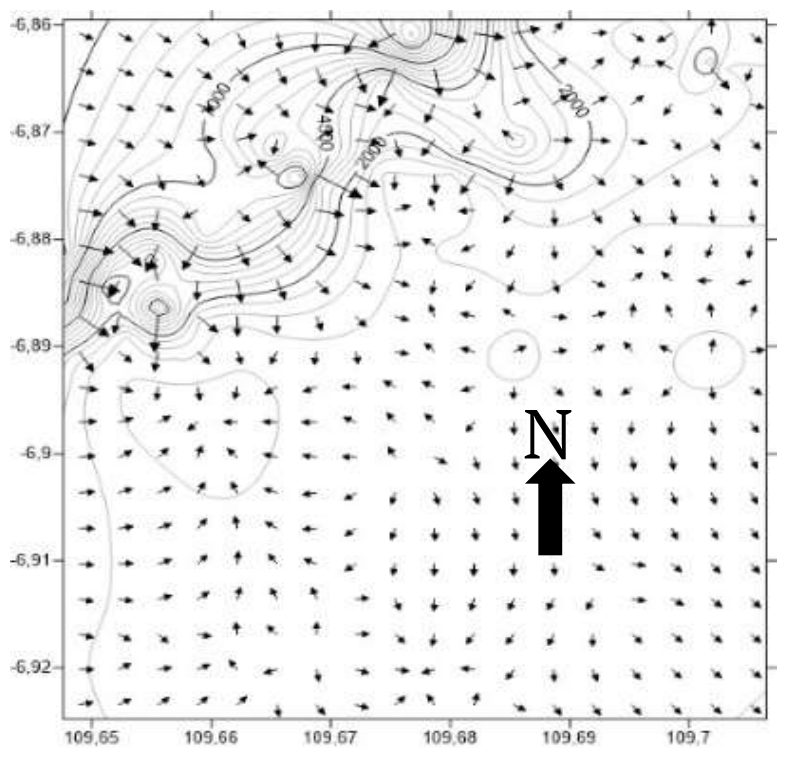

Figure 13. Pattern and flow direction of $\mathrm{Cl}^{-}$.

The dispersion pattern and flow direction were influenced by the distance and magnitude of the measured parameter value. According to Figure 8 to Figure 10, the direction of the dominant dispersion leads to the south or away from the coast and extended eastward. This means the parameters' concentration decreased with the location of groundwater samples which was discovered to be away from the coast. However, due to the significant efforts required to provide a relevant map, the sentence was modified to make the use of the map avoidable.

This means the concentration values of TDS, EC, and $\mathrm{Cl}$ - reduced as the groundwater samples are farther away from the coast This dispersion pattern was influenced by tidal flood or sea-level rise caused by Bremi and Tirto rivers. The river was unable to accommodate sea tide loads because the inflow discharge is smaller than the sea tide discharge thereby causing seawater intrusion and shallow groundwater pollution. This is line with the findings of Melo, M.T.C, (2015) that seawater intrusion is not only influenced by excessive pumping or groundwater exploitation but also because of the changes in land-use, recharge area conditions, and rising sea levels due to global warming.

\subsubsection{Dispersion mapping of seawater intrusion}

This was based on the groundwater quality parameters with reference to the 1986 Ad Hoc Sea Water Intrusion (PAHIAA) Committee Decree's classification of water quality to fresh, rather brackish, brackish, salty, and brine. Moreover, the values of electrical conductivity (EC), total dissolved solids (TDS), and chloride $\left(\mathrm{Cl}^{-}\right)$were used for analysis.

Table 2. Intruding distance from the coastline

\begin{tabular}{ll}
\hline Parameter & Intruding Distance $(\mathrm{km})$ \\
\hline TDS & 6.52 \\
EC & 6.52 \\
$\mathrm{Cl}^{-}$ & 7.22 \\
\hline
\end{tabular}

The table shows the seawater intrusion in Pekalongan coastal area intruded up to $6.52 \mathrm{~km}$ for TDS and EC while the farthest was $7.22 \mathrm{~km}$ and recorded for salinity $\left(\mathrm{Cl}^{-}\right)$. All dispersion directions were observed to be towards the south and away from the coast while the seawater content found there was due to the sea level rise from tidal floods inundating the region. Meanwhile, the maps of seawater intrusion dispersion are presented in Figure 14 to Figure 16 based on total dissolved solids, electrical conductivity, and chloride parameters. 


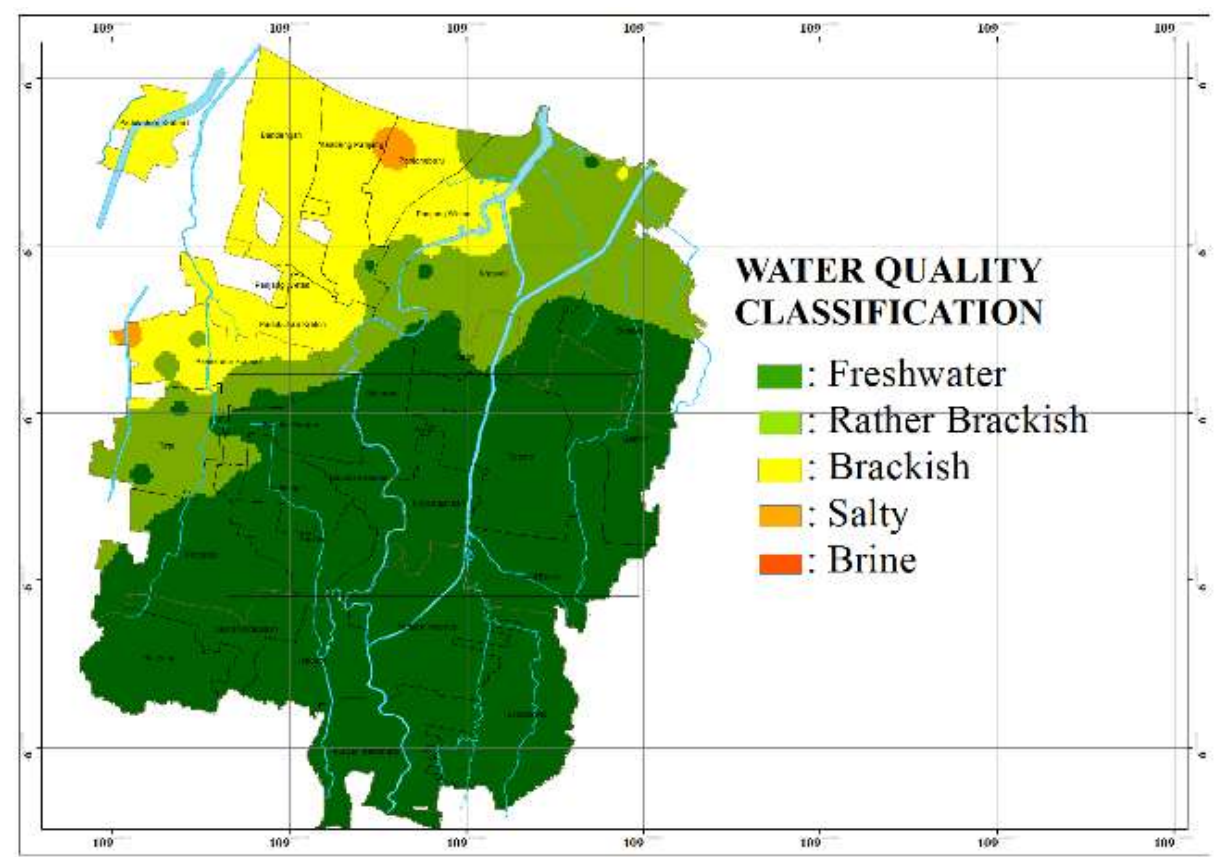

Figure 14. Dispersion map of seawater intrusion based on the TDS parameter.

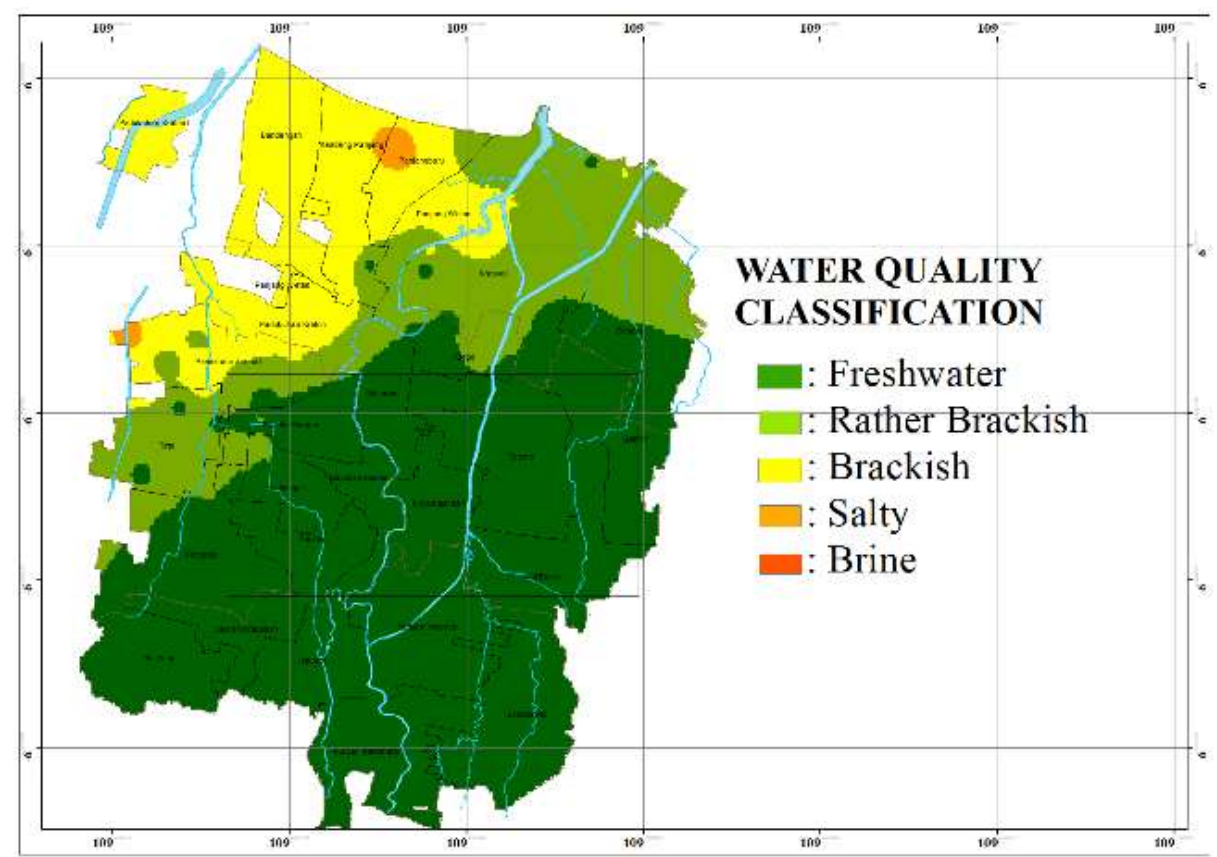

Figure 15. Dispersion map of seawater intrusion based on the EC parameter. 


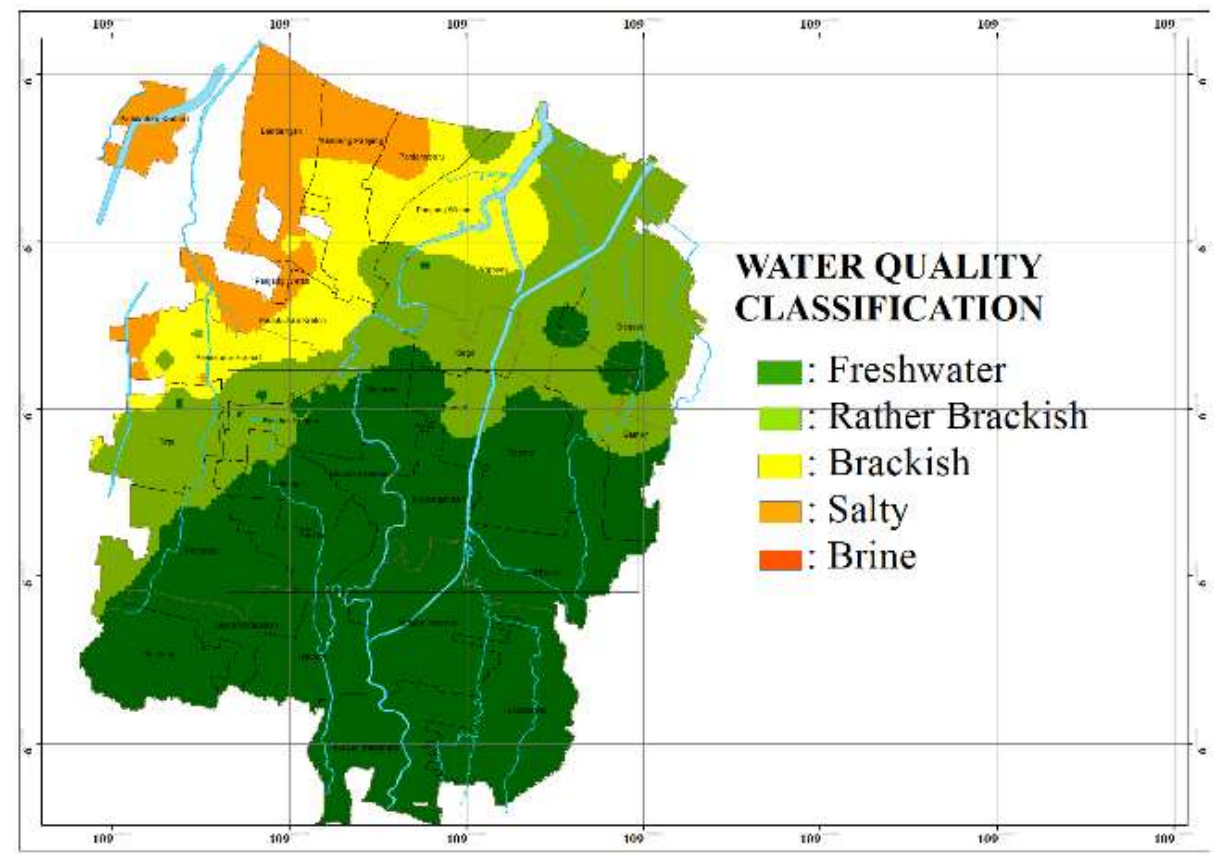

Figure 16. Dispersion map of seawater intrusion based on $\mathrm{Cl}^{-}$parameter.

The farthest location affected was in Pringrejo Village, West Pekalongan District, and the tide was observed to be propagating inland while the neap flows back to the sea through Bremi and Tirto Rivers. Meanwhile, the area close to these two rivers mostly has "rather brackish" to "salty water”. The analysis showed TDS, EC, and CL distributed in the Pekalongan freshwater zone reached $28.59 \mathrm{~km}^{2}, 28.36 \mathrm{~km}^{2}$, and $23.95 \mathrm{~km}^{2}$ respectively. Meanwhile, the freshwater zone in the South, East, West, and North districts was $11.26 \mathrm{~km}^{2}, 6.52 \mathrm{~km}^{2}, 5.81 \mathrm{~km}^{2}$, and $1.35 \mathrm{~km}^{2}$ respectively as shown in Figure 17.

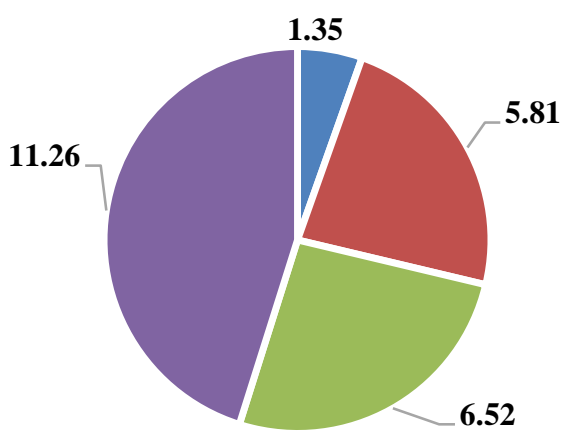

$$
\begin{array}{ll}
\text { - North Pekalongan } & \text { - West Pekalongan } \\
\text { = East Pekalongan } & \text { - South Pekalongan }
\end{array}
$$

Figure 17. Diagram of average availability of freshwater zone $\left(\mathrm{km}^{2}\right)$ in the Pekalongan coastal area.
The analysis and mapping showed the villages in North Pekalongan District with freshwater zone are concentrated in a small portion of the southern part of Degayu Village and the southern part of Krapyak with a total area of $1.35 \mathrm{~km}^{2}$. However, all other villages in North District including Padukuhan Kraton, Bandengan, Kandang Panjang, Panjangbaru, Panjang Wetan, Krapyak, and Degayu have been exposed to intrusion with a rather brackish to salty water quality. This study, despite being conducted in 2019 , was still in accordance with the findings of a 2013 research which showed the coastal area of North Pekalongan District has fresh groundwater with EC $<650 \mu \mathrm{mhos} / \mathrm{cm}$ in the south and northern boundary through Dukuh, Krapyak Kidul to Degayu section. Moreover, rather brackish groundwater with EC between 600 $\mu \mathrm{mhos} / \mathrm{cm}-1,500 \mu$ mhos $\mathrm{cm}$ was found in the middle including Kandang Panjang, Panjang Wetan, Krapyak Lor, and partially in Degayu village. Brackish groundwater with EC > 1,500 $\mu \mathrm{mhos} / \mathrm{cm}$ was discovered in the north covering Bandengan, Panjang Wetan, Kandang Panjang, Panjangbaru, and Degayu villages (Hidayat, M.R, 2015). It is, however, predicted that in 4 years there would no longer be freshwater in 
Padukuhan Kraton Village due to decreasing groundwater quality caused by seawater intrusion.

\section{CONCLUSION}

Pekalongan is a $46.972 \mathrm{~km}^{2}$ coastal area. The groundwater quality in this region has been affected by seawater intrusion towards $6.53 \mathrm{~km}$ southward based on TDS and EC and $7.22 \mathrm{~km}$ with $\mathrm{Cl}^{-}$parameters. A total area of $23.03 \mathrm{~km}^{2}$ has been affected and was observed to have spread $4.34 \mathrm{~km}^{2}$ to the West, $0 \mathrm{~km}^{2}$ to the South, $14.39 \mathrm{~km}^{2}$ to North, and $1.28 \mathrm{~km}^{2}$ to the East district. The intrusion was not only due to the continuous use of shallow wells but also significantly associated with the sea tides through tidal flooding caused by the Bremi and Tirto rivers.

\section{DISCLAIMER}

The authors declare no conflict of interest.

\section{ACKNOWLEDGMENTS}

The authors appreciate the Water Resource Engineering Division Laboratory, Department of Civil and Environmental Engineering, IPB University for providing the measurement instruments. They are also grateful to the Indonesian Geospatial Agency (BIG) for the provision of shapefile data as well as the Pekalongan residents for permission to take well samples.

\section{REFERENCES}

Drapper, N. R., \& Smith H., 1981. Applied Regression Analysis. Etobicoke: John Wiley and Sons Ltd. Canada.

Hadi, B. S., 2013. Spatial Interpolation Methods in Geography Studies (Brief Reviews and Sample Applications). Journal of Geomedia, 11(2), pp. 235252
Hidayat, M. R., 2015. Mapping of Seawater Intrusion of North Pekalongan District, Semarang: Undergraduate Thesis Report. Universitas Negeri Semarang.

Kusumarini, S., 2013. Seawater Intrusion Prediction Based on Value of Electrical Conductivity and Total Dissolved Solid in Tangerang Regency, Bogor: Undergraduate Thesis Report. Department of Civil and Environmental Engineering. IPB University.

McNeil, V., \& Cox, M. E., 2000. Relationship Between Conductivity and Analyzed Composition in A Large Set of Natural Surface-water Samples, Queensland, Australia. Journal of Environ. Geol., 39, pp. 1325-1333.

Melo, M. T. C., 2015. Coastal Aquifers Understanding Saltwater Intrusion. Lisbon: Tecnico Lisboa.

Naderi, M. N., Kermani, M. R., \& Barani, G. A., 2013. Seawater Intrusion and Groundwater Resources Management in Coastal Aquifers. European Journal of Experimental Biology, 3(3), pp.80-94.

Pasaribu, J. M., \& Haryani, N. S., 2012. Comparison of Interpolation Technical DEM SRTM Using Inverse Distance Weighed (IDW), Natural Neighbor, and Spline Method. Journal of Remote Sensing, 9(2), pp.126-139.

Rusydi, A. F., 2018. Correlation Between Conductivity and Total Dissolved Solid in Various Type of Water: A Review. IOP Conf. Series: Earth and Environmental Science 118012019.

Thirumalini, S., \& Joseph, K., 2009. Correlation Between Electrical Conductivity and Total Dissolved Solids in Natural Waters. Malaysian Journal of Science, 28, pp.56-61.

Widada, S., 2007. Phenomenon of Seawater Intrusion in Pekalongan Coastal Area. Journal of Marine Science, 12(1), pp.45-52 